\title{
LINGUO-CULTURAL CHARACTERISTICS IN UZBEK REFERENTIAL UNITS
}

\author{
Akhmedova Nargiza Shikhnazarovna \\ $\mathrm{PhD}$, Associate Professor \\ Alisher Navai Tashkent State University \\ of the Uzbek language and literature, Uzbekistan
}

Article DOI: https://doi.org/10.36713/epra3950

\begin{abstract}
Referential units are speech elements that represent not only the function of addressing, encouraging, calling, but also the subjective attitude of the speaker towards the recipient.

Not only connotative referential units indicate the addressee of the speech, but also characterize, evaluate it, and provide speech impression and influence through the connotative expression. There are a variety of ways in which speech is used to describe the subjective attitude of the speaker to the listener, such as being kind, expressing enjoyment, respect, satisfaction, anger, hatred, and discrimination.

The expression of the connotation through the referential units in the communication is directly related to the national customs, traditions, spirituality, worldview and social environment of the Uzbek nation, its geographical location, climatic features, and interpersonal relations among people, natural conditions, religious views and beliefs.

Connotative referential units are found on the basis of presuppositions such as important social characteristics of the listener, i.e. their age, sex, role in society, work position, being familiar or not, age variations, the social status of the listener - high, low or equal, the formal or informal status of the conversation.
\end{abstract}

KEYWORDS: Uzbek language, referential units, connotation, presuppositions, pragmatics, linguocultural, stylistic devices.

\section{INTRODUCTION}

It is a well-known fact that a sentence is a syntactic unit, which is used as the main instrument for formulating, expressing and narrating ideas, formed by the grammatical rules of a particular language. The main function of the sentence is communicative, that is, the expression and expression of opinion.

The idea expressed by the speaker in a sentence is communicated to the listener by means of referential units. The speaker draws the attention of the listener through these units, expressing his or her negative or positive attitude for the latter. Consequently, functions of referential units consists not only of referring or stimulating to an action, but also expressing additional subjective attitude of the speaker, that is, becoming a stylistic device and obtaining a semantic connotation.

Connotation is a macro component of semantics that specifies expression, and appears in the naming process as an assessment of the reality. Therefore, the main task of the connotation is defined by the majority of experts as an influencing and interaction with speech pragmatics.[1]

When examining the semantic structure of a word, many researchers note two types of connotations: inherent connotation, which represents a connotative meaning of a word taken out of context, and adherent connotation that is created in a given context[2]. Referential units that are widely used in our everyday life, in communication, are characterized by adherent connotation - pragmatic meaning that appears in communication, directly related to the national spirit, worldview, customs, and culture of the speaker.

In the scientific literature, "connotation" is noted as being attached to denotation[3], from Latin prefix "cun, con" - "together" and "notare" - "to denote"; the connotative meaning possesses additional expressive and stylistic meanings[4] of a language unit, extra meaning that surrounds it[5].

Referential units are divided into two main categories that are units with denotative meaning and units that have both denotative and connotative meanings. This takes place as referential units are not used only in order to attract attention, but also emotional connotative meaning[6].

A referential unit is used to attract, motivate, call someone's attention, which, in its turn, represents its denotative meaning, whereas the connotative meanings of such units arise from the expressions of affinity for the person or subject that is being added in 
addition to the denotative meaning. This means that the referential units can be divided into two groups:

1. Referential units, which do not contain connotative meanings;

2. Referential units, which contain connotative meanings.

The referential units of the first group attract the attention of the listener by naming or calling, they convey the meaning or encourage the listener to do some kind of action. They do not express the subjective attitude of the speaker such as respect, intimacy, anger. Therefore, these kinds of referential units are often used in a formal speech. Compare:

"Kitob, sen bo'lmasang balki kun yorishmasdi!" (I.Gani)

("Book, if it weren't for you, maybe, there would not be light!").

"Oq yo'l, yosh muallim!" (M. Muhammad Dost)

('Safe travel, young teacher?').

The above examples illustrate that the referential units that do not have a connotative meaning are represented mainly by semantic content that does not contain stylistic coloring or emotiveness; they mostly are constructed of neutral lexemes and have a nominative function. In such units of reference, the purpose of the speaker is to capture the attention of the listener.

The referential units are used mostly in conversational, belles-lettres, popular (publicist) and partly official-business styles, while being hardly used in and scientific ones. Referential units, which do not contain connotative meanings are generally observed in the official styles.

The referential units are one of the key factors that determine the culture of communication, thus not only expressing speaker's attitude to the listener, but also demonstrating their level of literacy and culture. Referencing is important in communication, and most of the times it determines the quality of the further communication in general.

The referential units sophisticate both semantics and structure of the sentence. They are meant to draw the attention of the listener to information that is to be delivered during the communication. In addition, they indicate the attitude of the speaker toward the listener. In such statements, subjective content of the speaker is added to the dictum, which is considered to be an objective content, thus revealing the appeal, involvement, and motivation attitude towards the listener. For example: "Kuyov bola, uy-puying bormi?" ("So, bridegroom, do you have any family home at all?") (T. Malik). The speaker's intention is to find out if the groom has a home. The bridegroom the listener-is being approached for information. In such a discourse, the number of subjects is also expanded: the listener is added to the subject that produces a specific action in an objective state. Therefore, the sentence is semantically complicated.

In addition, the expression of the connotation in the referential units depends on the psychological state of the speaker, the pragmatic aspect of the speech process, and the factors such as the formal or informal nature of the interaction, which in turn derives the classification of evaluative-descriptive and emotional characteristics[7].

In the speech, the dependent component of the attributive compound represents an expression, and as an actuator, representing the dominant component implicitly. It results in the creation of metonymic derivative meaning that is expressed in a pragmatic meaning[8]. The metonymic derivative expressions also express a strong connotative meaning when used as the unit of reference: "Hoy shapka, menga qara" (Collocation) "Hey hat, look at me). In this sentence, the reference unit is used in this way as a result of the ellipsis. It also has the intention of expressing the speaker's negative attitude toward the listener.

The referential units should be understood as a link between objectivity and subjectivity based on all the meanings of the words in the unit of reference, as most of connotative expressions contain certain symbols of the denotative meaning. The speaker does not ignore this meaning communicating its pragmatic purpose. For example, in the sentence: "Listen to my words mylamb" - "my lamb" represents connotative sense; it is understood that, the initial meanings of the word represent the ideas of "small", "young", "offspring of an animal", used as an expression of a positive attitude. In the sentence the meanings of "small" and "youth" have been preserved, while "offspring of an animal" is replaced with one of the human.

It should be noted that evaluation is not limited to the speech environment or the evaluator. Social environment, geographical location, climatic features, and interpersonal relations among people, natural conditions, religious views and beliefs also play an important role.[9] For example, Uzbek people pamper their children using names of animals' offspring, such as "lamb", "calf", "colt" and "foal". "Adoyi tamom bo'ldingku, toychog'im" (O. Yakubov) (Oh, you are wasted, my foal). "Bo'talog'im, o'zingdan gapir" (M.Yusuf) (My calf, speak of yourself.). "Alla, qo'zim, allayo; Shirin so'zim allayo" (Lullaby) (Sleep, my lamb, sleep; Sleep my sweet worded, sleep). "Yurakkinamni qon qilding-ku, qulunim" (O. Yakubov) (Oh, you have made my heart bleed, my colt.

The referential units in these examples are exclusively of Uzbek ethnicity, where the connotative meaning is at the forefront of the denotative. Because of the fact that such units of reference are used exclusively based on the national characteristics of the language, their equivalent in another language cannot 
be found[10]. As it turns out, referential units are tools that reflect nationality.

While the words snake and frog is considered to be a positive form of assessment in Japanese culture, in other nations it is considered to be a negative one. In the Czech language, the word frog is a sign of a girl's beauty (positive), but it only awakes negative characteristics in the minds of Uzbek people:

O you weak frog,

Don't give up,

Issa is on your side (Japanese poem).

In such appeals resulting from the secondary nomination, the evaluation is based on a contractual relationship and context. The individual traits of lexemes form the basis for pragmatic formation by means of meaning migration during speech. As a result, the evaluation is expressed on the basis of the contractual relationship between the speaker and the listener, that is, the positive or negative features of the animals present in the general knowledge create the foundation for the assessment and the connotation during the communication.

It is well known that in the process of naming, the speaker not only takes into account the essential features of the addressee, but also expresses their emotional attitude towards the latter.[11] After all, when a speaker names the listener by referring names, he or she performs the action for the sake of the one who listens, not themselves[12].

It is obvious that expressively colored connotative referential units are usually the result of secondary nominations. The only internal form is the means that connects the speaker's - the subject's assessing relation to the object. For example, the word "cunning" is a traditional assessment of a person's character in the Uzbek language. The use of the word " $f o x$ " in relation to a person shows a figurative expression of the presence the highest level of cunning characteristics. For Uzbeks, as well as for many other nationalities, foxes represent the highest standard of guile[13].

It is well-known that the process of interaction takes place in different spheres of life, in different environments. The referential units used in communication are directly related to pragmatic presuppositions. Because the speaker addresses the listener based on his prior knowledge, that is, he chooses the appropriate reference unit based on the age, occupation, social status, and familiarity with the listener and to the extent of how formality or informality of the communication. That is, the common knowledge fund of the speaker is expressed in the form of presupposition in referential units. The same presupposition can be determined, depending on what referential units are used by the speaker.

Depending on whether the speaker is familiar or unfamiliar with the listener, referential units can contain the presupposition of "familiar listener" and "unknown listener".
1. The units of reference with the presumption of a "familiar listener" are represented by nouns, kinship terms, and various descriptive expressions, combinations formed on the basis of assessing or characterizing a particular character of the listener. For example: 'Do'stim, sen adabiyotimizga astoydil xizmat qilding." ("My friend, you have contributed a lot into our literature (S. Ahmad).

2. Units of reference with the presupposition of the "unknown listener".

a) Lexemes representing kinship are used in the form of reference to an unknown listener. It is well known that the Uzbeks are hospitable, open-hearted and compassionate, and often refer to strangers by the names associated with family relationships. These names are based on the gender and age of the listener. For example: "Iya, qiziq ekansiz-ku, singil!" (Oh, are you serious, little sister!), - the lame confectioner shouted loudly (U. Hashimov).

Referential units can also be classified according to the age categories of the listeners containing presuppositions such as "young listener", "older listener" and "peer listener":

According to the formal or informal nature of the relationship, the referential units can denote formal and informal characteristics.

1. Informal units of reference. These are mostly used in spoken and belles-lettres style. In this case, referential units are chosen based on the speaker's personal and subjective attitude. Referential units, which contain connotative emotional expression, carry out assessment features: "Ha, erka qizalog'im, sen mening kelajagim umidisan" ("Yes, my sweet daughter, you are the hope of my future") (S.Ahmad).

2. Official referential units: For example: "Muhtaram ilm-fan ahli! Aziz birodarlar!" ("Dear scholars! Dear brothers!") (I. Karimov).

Uzbek people used the words "khazratim, amirzodam and shakhzodam" towards referring the heads of state such as kings, princes and even parents, which in a broad sense showed respect to the listener. Such use is due to the fact that the listener is of a high social level, rather than age or kinship. Writer P. Kadirov in his book "Yulduzli tunlar" ("Starry Nights") reinforces the disrespect of Aisha-begim, the wife of Zakhiriddin Muhammad Babur, towards her king husband, when the latter was defeated in the battle with Sheibani-Khan:

.... - I do have no secret to conceal from my kin, my Mirza!

It was obscure that Aisha-begim, who once glorified Babur by calling him "khazratim" (my dear lord), now was appealing to him with some belittling because of his defeat and misfortune, just as his Uncle, the khan of Tashkent Mahmud Khan did. 


\section{CONCLUSION}

Summarizing all the above analyzed, it is possible to refer to one listener with different forms of communication, depending on their circumstances and conditions of the communication. Everyone has their place in the family, among friends, community and workplace. Consequently, referential units are the key words that indicate the status of communication, the interactions of the speaker and the listener, the role of the listener in society and the family, their age, gender, and possess specific (nonnaming) connotations and presuppositions in the text.

\section{BIBLIOGRAPHY}

1. Teliya, V.N. (1986). Konnotativnyy aspekt semantiki nominativnyx edinits. (p.7). Moskva: Nauka.

2. Qilichev, E.(1982). Badiiy tasvirning leksik vositalari. (p.11). Toshkent: Fan.

3. Mirtojiev, M.(1992). Tovushlardagi ma'nolar.(p.7). Toshkent: O'zbekiston.

4. Hojiev, A. (2002). Tilshunoslik terminlarining izohli lug'ati. (p.52). Toshkent: O'zbekiston milliy ensiklopediyasi.

5. Bozorov, O.(1995). O'zbek tilida darajalanish.(p.76). Toshkent: Fan.

6. Aitova, X.R. (2003). Rechevye etiketnye formuly obrasheniya $k$ sobesedniku (na materiale russkogo i angliyskogo yazykov): PhD diss. thesis. (p.16). Tyumen' // http://orel.rsl.ru.

7. Glazova, O.G. Ekspressivnye formy obrasheniya $v$ aspekte russkoy razgovornoy rechi // Rossiyskiy universitet drujby narodov. /I http://fixed.ru/prikling/conf/stilsistl/eksprxsbhavu .html.

8. Tohirov, Z.(1985) Metonimik hosila ma'nolarida pragmatik semalar (p.28) // O'zbek tili va adabiyoti. - Toshkent, 1985. No3.

9. Mamadalieva, M. (1997). O'zbek tilida nominativ birliklarning konnotativ aspekti. (p.60). Namangan.

10. Parfenova, A.A. Formy obrasheniya $v$ sovremennom angliyskom yazyke $i$ vozmojnye puti ix perevoda na russkiy. // http://www.phil.pu.ru/depts/02/anglistikaXXI_01/ 46.htm.

11. Le, V.N. (1989). Vidy xarakterizatsii adresata $v$ formax russkogo obrasheniya: PhD diss. thesis. (p.23). Voronej.

12. Gak, V.G. (1974) K tipologii lingvisticheskix nominatsiy //Yazykovaya nominatsiya. (p.241). Moskva: Nauka.

13. Mamadalieva, M.(1997). O'zbek tilida nominativ birliklarning konnotativ aspekti. (p.41). Namangan.

14. Qodirov, P.(2002). Yulduzli tunlar. (p.261). Toshkent: Sharq. 